DOI 10.38129/ Ann.Yur.Ist.2019.3.3.4.10

УДК 343.812:343.825:316.354.2: (376.112.4:343.815)

\title{
РЕЛИГИОЗНАЯ И ПСИХОЛОГИЧЕСКАЯ ПОМОЩЬ ЗАКЛЮЧЕННЫМ В НОВЕЙШЕЕ ВРЕМЯ: ПОДХОДЫ И МОДЕЛИ
}

\author{
МАРИЯМ АРПЕНТЬЕВА (Калуга, Российская Федерация)*
}

Введение. В новейшее время исправительная система стран ЕС носит преимущественно характер восстановительный и реабилитационный. Она существенно и качественно отличается от таковой в США и, особенно, в России. Эта система признает в преступнике человека, предписывая человеческое с ним обхождение, требующее тем более гуманной осторожности, что это - человек больной, ошибающийся, страдающий ${ }^{1}$. Измеряя преступника человеческой меркой, она стремится создать относительно «нормальную» жизнь в тюрьме: жизнь на более осмысленных и нравственных началах, устраняя все вредное, все неестественное для человеческой природы и доставляя более средств для развития способностей, личности и души, не теряя надежды на исправление каждой личности: «..ни в одном преступнике не следует предполагать неспособности к исправлению». Даже приговоренные к казни и обреченные на пожизненное заключение исправляются ${ }^{2}$. Вопрос лишь в наличии у них и общества стремления, методов и ресурсов.

Исправительные модели: религиозная и психологическая составляющие реабилитации заключённых. Многие западные ученые (Э. Сазерленд, Д. Кресси, Д. Тафт, Т. Варне, У. Реклесс, Дж. Митфорд, А. Ройс, Г. Шнайдер, Р. Кристи) отмечали важность внедрения в работу пенитенциарных учреждений принципов, лежащих в основе исправительной системы: перевоспитание преступников вместо их наказания; применение научно обоснованных средств изменения личности нарушителя закона; индивидуальный подход; освобождение осужденного,

1 Арпентьева М. Р. Тюремная реформа в России XIX века // Советник юриста. 2015. № 12. С. 54-65; Арпентьева М. Р. Восстановительная юстиция: особенности и перспективы // Советник юриста. 2015. №9. С. 3-11; Арпентьева М. Р. Доктрина понимания и деятельность социального работника в ювенальной юстиции // Советник юриста. 2015. № 10. С. 5 8-76; Арпентьева М. Р. Психологическое сопровождение адвокатской деятельности // Советник юриста. 2015. №7. С. 29-45. 2 Миттермайер К. Ю. Смертная казнъ: По результатам научных исследований, успехов законодательства и опытов. СПб.: Тип. А. С. Голицына, 1864. 176 с. С. 88; 98-100. 
доказавшего свое исправление. Стремление к позитивному изменению заключенного ряд исследователей связывают с представлением о нем как о больном человеке, нуждающемся в специальном лечении / попечении. Наказание в форме телесного, психического или социального насилия, не несет воспитательной функции: человек превращается в объект насилия, которому наносится ущерб (унижение, стигматизация, разрушение здоровья и судьбы, доведение до самоубийства и т. д.).

Воспитательное воздействие должно помочь преступнику возвратиться в общество, жертве получить возмещение причиненного ей вреда, а обществу - избежать рецидивов, добиться примирения между преступником и его жертвой, восстановить и поддержать общественный порядок. Таким образом, тюрьма в странах ЕС относится к личности с заботливостью, терпением и «щекотливостью»: не стремится напоминать о его преступлениях в обхождении с ним. Служитель исправительной тюрьмы должен быть уравновешен и ценностно сформирован, гибок и готов ко всему и на все, включая самопожертвование, в рамках выполнения одной из самых сложных задач - задачи перевоспитания, реабилитации людей, однократно или систематически нарушивших и / или нарушающих нравственные и правовые законы. Для этого он должен заслужить уважение и доверие сотрудников и заключённых.

Н. М. Ядринцев писал: «доверие, такое сближение с человеком, конечно не может быть достигнуто ни приказанием, ни грубостью: оно может быть достигнуто только крайне деликатным обхождением, знанием человеческого сердца, и, главное, верою в лучшие наклонности человека. Не отчаивайтесь в людях, не показывайте вида, что считаете их совершенно испорченными... Покажите, что вы считаете их лучшими, чем они есть; покажите веру в их исправление, затроньте в человеке благородные мотивы: они есть в душе самых испорченных; и поверьте, что вы лучше добьетесь цели. Таковы правила, на которых должно держаться исправление»³.

Ф. М. Достоевский считал: «Всякий, кто бы он ни был и как бы он ни был унижен, хотя и инстинктивно, хотя и бессознательно, а все-таки требует уважения к своему человеческому достоинству. Арестант сам знает, что он арестант, отверженец, и знает свое место пред начальником, но никакими клеймами, никакими кандалами вы не заставите забыть его, что он человек. А так как он действительно человек, то следственно надо с ним и обращаться по-человечески. Боже мой! Да человеческое обращение может

3 Ядринцев Н. М. Русская община $b$ тюрьме и ссылке. Сост., авт. предисл. и примеч. С. А. Иникова. Отв. ред. О. А. Платонов. М.: ИРЦ, 2015. 752 с. С. 346-347; 680. 
очеловечить даже такого, на котором давно уже потускнел образ Божий... Я видел какое действие производило человеколюбивое обращение на этих униженных: несколько ласковых слов - и арестанты воскресали нравственно» ${ }^{4}$. Напротив, как показал опыт каторги и иных форм заключения, предполагающий большие или менышие телесные наказания (пытки) и ограничения прав, «от телесных наказаний грубеют и ожесточаются не только арестанты, но и те, которые наказывают и присутствуют при наказании. Исключения не составляют даже образованные люди».

Причина многих несчастий - не только в преступности людей, но и $b$ порабощенности их ненормальными условиями жизни, «варварских ее условиях», где нет уважения и изарит презрение, где поошряются безнравственность и люди не дорожат друг другом 5 . Так, говоря о женщинах на каторге, А. П. Чехов, «предвосхищая» многие воззрения М. Фуко, писал: «Человеческое достоинство, а также женственность и стыдливость каторжной женщины не принимается в расчет ни в коем случае; как бы подразумевается, что все это выжжено в ней ее позором или утеряно ею, пока она таскалась по тюрьмам и этапам»6. Тюрьма, согласно М. Фуко, - выражение сущности и лаборатория воспитания европейской личности Нового времени. Порядок лишения свободы до конца XVIII и начала XIX веков назван М. Фуко «великим заточением». «Классическая эпоха изобрела изоляцию, подобно тому как Средневековье изобрело отлучение прокажённых; место, опустевшее с их исчезновением, было занято новыми для европейского мира персонажами - «изолированными»» 7 .

Россия такого «великого заточения» не пережила, но ссылки и каторги России близки западным «заточениям» по характеру отношения к людям: «человеческий материал выбрасывается из общества, «о человеке не заботятся, его изолируют». Кроме того, «большим заточением» в русском обществе можно назвать крепостное право. «Великое освобождение», пришедшее вместе с тюрьмой, распускает изолированное население бастилий, бедламов, дифференцирует его в сеть дисциплинарных практик,

4 Достоевский Ф. М. Записки из Мертвого Дома. Достоевский Ф. М. Полн. собр. соч. и писем: в 30 т. Л.: Наука, 1972. С. 91.

5 Чехов А. П. Полное собрание сочинений и писем в 30-ти томах. Письма. Т. 14-15. М.: Наука, 1976. С. 131; 338.

6 Чехов А. П. Полное собрание сочинений и писем в 30-ти томах. Письма. Т. 4. М.: Наука, 1976. С. 251.

7 Фуко М. История безумия в классическую эпоху. СПб.: Университетская книга, 1997. 576 с. C. 70. 
позволяющих корректировать отношение человека к себе и миру. Великое освобождение России - в середине XIX века не сделало и этого: каторга продолжила традиции крепостничества, поменяв лишь «хозяина» рабов. И только. Дисциплинарная система, предполагающая ресоциализацию преступника, не выработана и не вырабатывается. В начале XIX века тюрьма является ведущим и единственным наказанием за все преступления, кроме смертной казни. В России существовал иной, надзорно-исправительный порядок, который был странной пародией на «правильное заключение», или, точнее, его более примитивной версией. Реформы под руководством К. К. Грота остались незаконченными, и, по сути, провалились. К началу XX века был создан ряд больших каторжнопересыльных тюрем в центре («централов»), но основным местом заключения остались старые остроги - ветхие, переполненные, уничтожающие своих жителей, которые включали ряд групп, в том числе ждущих этапирования. От ситуации временного лидерства, Россия вернулась «в хвост» тюремных реформ: «Рабское подражание западноевропейским образцам в области разрешения тюремного вопроса так же неудобно, как и в других областях. Пересаживая на нашу почву систему келейного заключения, не следует забывать, к каким горьким плодам привела эта система там, где она достигла своего рода идеального совершенства» 8 . При этом система ссылки отвечала сиюминутным потребностям государства, хотя и в стратегической перспективе блокировала его развитие в правовой и политической сферах. Без тюремной системы государство благополучно миновало стрессы, побуждавшие на Западе к реформам. В России реформы оказались ненужными, тюремная система по существу не реформируется уже несколько столетий. Это, в свою очередь, сыграло большую роль в изоляции России от идей Просвещения и развития гражданского общества и демократии в стране9. Тюрьма как принудительная ресоциализация человека является матрицей правильной и интенсивной его эксплуатации как индивидуального тела, а также матрицей его саморегуляции в процессе самореализации как элемента системы. Западная власть (государство) внедряется в жизнь и внутренний мир личности, блокируя саморазвитие. Каторга - формирование индивида как части коллективного тела,

8 Соколовский Н. А. Уголовное уложение. По поводу проекта Редакционной комиссии // Русское богатство. 1896. № 5. С. 120-129. С.129; Уголовное Уложение. Проект редакиионной комиссии. СПб.: Тип. Правительствующего Сената, 1895. 177 с. ${ }_{9}$ Gentes A.A. Exile to Siberia, 1590-1822. New York, Houndmills: Palgrave Macmillan. 288 pp. 
коллективной самореализации. Ресоциализация заключённого идет параллельно системе лагерно-уголовного мира, она проникает во все структуры общества. При этом российское государство на протяжении веков то ли не стремится, то ли не способно обеспечить цивилизованный минимум социального надзора за человеком, поддержку человека. Противостоит этим двум моделям - европейской тюрьмы и русской каторги - «культура себя» - «рефлексивные и волевые практики, посредством которых люди не только фиксируют себя правилами поведения, но ищут, как трансформировать самих себя, как модифицироваться в их единичном существовании и как сделать из жизни произведение, которое имеет некоторую эстетическую ценность и отвечает некоторым критериям стиля» ${ }^{10}$.

Обычное человеческое «Я» на Западе оказывается унифиицированным и психологически ненаполненным, неприкосновенность частного мира не означает наличия заботы о себе, подлинном «Я». К примеру, А. П. Чехов стремится отойти от социально «правильной» настройки жизни к «заботе о себе», предполагающей смешение и пересечение возрастов, профессий, болезней и здоровья и т. д. ${ }^{11}$. Аналогичные выводы фиксируют Дж. Агамбен, А. И. Солженицын и В. Т. Шаламов ${ }^{12}$. Еще один важнейший автор, «уточняющий» осмысление этих вопросов - Г. де Мопассан: преступление без наказания у него резко контрастирует с наказанием без преступления у А. П. Чехова. Однако, общий посыл - верить в каждого человека - объединяет их работы ${ }^{13}$. Общий посыл - необходимость собственной этической и эстетической работы, направленной по поиск самого себя, истинного «Я», заботы о нем. С точки зрения религиозной, истинное «Я» - это душа человека, в том числе в контексте его веры в Бога, сам Бог. Забота о «Я»- это служение Богу, в себе и во всем мире. «Помните, самое главное: лагерь - отрицательная школа с первого до последнего дня для кого угодно. Человеку - ни начальнику, ни арестанту не надо его видеть. Но уж если ты его видел - надо сказать правду, как бы она ни была страшна... Со своей стороны я давно решил,

${ }^{10}$ Foucault M. L'Usage desplaisirs. Paris, 1984. P. 17.

11 Фуко М. Надзирать и наказывать. Рождение тюрьмы. М.: Ad Marginem, 1999. 480 с.

12 Агамбен Дж. Ното sacer. Суверенная власть и голая жизнъ. М.: Европа, 2011. 256 с.; Шкуратов В.А. А.П. Чехов и М. Фуко: российская каторга или западная тюрьма? // Политическая концептология. 2013. № 1. С. 34-43.

13 Мопассан Г. Собрание сочинений: Творчество А.П. Чехова: рецепиии и интерпретации. Сб. материалов Международной научной конференции. Ростов-на-Дону, 1-4 октября 2012 года / Ларионова М.Ч. (ред.). Ростов н/Д: изд-во «Foundation», 2013. 230 с. 
что всю оставшуюся жизнь я посвящу именно этой правде», - так сформулировал свое кредо В. Шаламов ${ }^{14}$. Внешне он противопоставил свою позицию позиции А. Солженицына, считавшего тюрьмы и т. д. важной школой человеческого духа. Однако, внутренне, в его работах также прослеживается понимание «трансцендентного» смысла тюрьмы. Начиная с трансгрессии, отказа от норм повседневности «обычных» людей, человек приходит к новому пониманию себя и отношений между людьми, переосмыслению этих норм, более глубокому и разностороннему их пониманию и исполнению, включая нормы и требования взаимопомощи и служения . Однако, как отметил С. С. Хоружий, глубоко уважавший В. Шаламова, - «даже принести о данном порядке жизни прямое свидетельство, выложить, рассказать его было травматично, опасно»15.

В структуре современной социально-психологической помощи осуждённым выделяются пастырское служение (священнослужители) и профессиональное светское служение (психологи).

В своей работе в пенитенциарных учреждениях специалист часто сталкивается - как с одним из важных - вопросом о соотношении воспитательной и консультативной функций, а также соотношением светской психотерапии и пастырского служения ${ }^{16}$. В обычной ситуации (вне пенитенциарного учреждения) речь, как правило идет о том, что «светский помощник» - психолог - заменяет и / или помогает пастырю. Их способы (технологии) работы могут быть сколь угодно близки, если соблюдаются основные принципы пастырской и консультативной помощи 17 . Однако, многие пастыри, в отличие от психотерапевтов, отмечают, что различия велики и психологический подход «бездуховен», и, потому, подчас

14 Шаламов В. Переписка с А. И. Солженицыным // Шаламов В. Новая книга: Воспоминания. Записные книжки. Переписка. Следственные дела. М.: Изд-во Эксмо, 2004. 1072с. С. 652.

15 Хоружий С. С. Предисловие. Феномен человека в его эволюизии и динамике: Труды открытого научн. семинара. Отв. ред.: С. С. Хоружий, О. И. Генисаретский. М.: Институт философии РАН, 2009. 87 с. С. 3; Borowski T. Here in Our Auschwitz and Other Stories (The Margellos World Republic of Letters). Yale: Yale University Press, 2016. $352 \mathrm{p}$.

16 Арпентьева М. Р. Психологические аспекты правоохранительной деятельности: эссе по юоидической психологии. Калуга: КГУ, 2017. 270 с.

17 Миттермайер К. Ю. Смертная казнь: По результатам научных исследований, успехов законодательства и опытов. СПб: Тип. А. С. Голицына, 1864. 176 с.; Сурожский А., митрополит. Беседы о молитве. СПб: Сатисъ, 1996. 143 с.; Флоренская Т. А. Мир дома твоего: Человек в решении жизненных проблем. М.: Русскій Хронографъ, 2009. 480 с. 
неприемлем. Вместе с тем, большая часть исследователей и практиков говорит о взаимном обмене, сходстве и различиях светской и пастырской помощи ${ }^{18}$, в том числе в рамках социально-психологической и духовнонравственной помощи в рамках пенитенциарных учреждений, в силу личностных и ситуативных особенностей контакта специалиста и осужденного, приобретающей тот или иной акцент.

В тюрьме, однако, любая человеческая помощь оказывается целительной, позволяя человеку сохранять в себе человека: признанного и существующего для других людей и имеющего собственную внутреннюю и внешнюю территорию и время бытия. Поэтому помощь священнослужителей, психологов и, в некоторых случая, остального персонала тюрьмы или СИЗО, способного признавать в «зеках» людей, может быть весьма вдохновляющей и побуждающей к духовнонравственному развитию, необходимой для выживания и скрадывающей беспросветные будни обречённых умереть духовно и физически и уничтоженных социально заключенных. При этом значительная часть такой помощи связана с собственно психологической поддержкой и, в меньшей мере, социальной. Основная задача - поддержать душу заключённого, в том числе средствами социальной поддержки. Кроме того, в некоторых тюрьмах и СИЗО проблема социальной поддержки не является насущной, а в других - где людей целенаправленно или «из лени» продолжают унижать и лишать достоинства и прав, - даже небольшая поддержка может оказать значение судьбоносное и жизненное.

Официальная статистика умалчивает, сколько заключенных умерло или было убито в стенах СИЗО и тюрем России и иных стран СНГ за последние десятилетия. Однако, та часть сообщества, которая соприкоснулась с тюрьмами, пытками и произволом в отношении заключённых, никаких иллюзий о справедливости, законности и т. д. современной правоохранительной и правозащитной систем, систем исполнения наказаний, не разделяет. И сколько бы психологи, священники и иные специалисты не пытались исправить «имидж» сотрудников правоохранительной и правозащитной систем, сколько бы попыток «оптимизации психологического сопровождения» заключенных не декларировалось, все исчезает в масштабном и спланированном насилии, рабстве и предательствах, к которым побуждает сотрудников исполнительной системы существующая практика «содержания»

18 Перистый Е., игумен. Пастырская помощь душевнобольным // Консультативная психология и психотерапия. 1998. № 1. С. 151-181. 
заключенных. Не удивительно, что, отчаявшись изменить что-то на уровне социальных и физических отношений, люди, лишенные права считаться людьми и называемые «зэки», жаждут психологической и духовной помощи, ждут подтверждения того, что они - люди. Люди, искореженные своими и чужими выборами и поступками, преступлениями и «благодеяниями», пестуемые преступным и отчужденным социумом низменными желаниями и инстинктами, потерянными нравственными ориентирами и смыслами жизни, судьбой, душой, личностью, а подчас, и все больше во времени пребывания в тюрьмах, - телом. Они нуждаются в поддержке, помощи в самопонимании, а также помощи в понимании мира, гармонизации как исправлении и восстановлении связей с миром и обществом.

В общем и целом люди расположены помогать друг другу без принуждения: власть и государство, законы, централизованное управление не нужны, чтобы поступать справедливо и человечно. Однобокость власти и превознесение закона и репрессий подавляет, с точки зрения многих исследователей, природную склонность к сотрудничеству и милосердию19.

Чем «сильнее» государство, тем, обычно, пассивнее общество: государство начинает стремится ко все большей власти и контролю, не считаясь с уже достигнутыми и не исправляя своих ошибок, приводящих к росту «сбоев» управления.

Общество в таком государстве переживает состояние равнодушной аномии, осознавая ненужность и бесполезность собственной активности и, таким образом, еще более провоцируя репрессии и контроль со стороны государства. В ацефаличесих сообществах, где государство слабо или отсутствует, взаимная помощь и солидарность - естественный закон, как и взаимная борьба; однако, для прогрессивного развития первая важнее: сражаясь, люди учатся сотрудничать. Иногда взаимопомощь сводят к родительским чувствам, привязанности, инстинкту заботы о потомстве. Однако, это не так. Взаимопомощь помогает виду развиваться, на этом фоне понятно, что соперничество полезно, если дело не доходит до взаимного уничтожения. Взаимопомощь как благотворение, опирающееся на принципы нравственности, социальной справедливости, ответственности и участия, - это благотворение, учитывающее будущее, его вероятные варианты, возможности и ограничения, которые существуют и могут существовать у людей и организаций, которым оказывается та или

19 Кропоткин П.А. Взаимная помощь среди животных и ююдей как двигатель прогресса. М.: Голос труда, 1922. XIII. 342 с. 
иная помощь при тех или иных условиях. Таким образом, речь идет о том, чтобы учить общество помощи и взаимопомощи, так, чтобы люди могли видеть и непосредственные и отдаленные следствия своих усилий, также их реальную значимость и воплощение в конкретные результаты деятельности организаций, сообществ, государства, страны, мира.

Помогая другим, заботясь о других, люди и мир становятся на путь развития: не только технологического. Общество, социальное служение обществу, должны быть ориентированы не просто на помощь наиболее нуждающимся, но на поддержание, трансляцию и укрепление роли нравственности; идеология служения не должна становиться идеологией служения обществу безнравственных людей. Служение не может быть понято вне его нравственных императивов и вне понимания того, что оно компонент социально-политического взаимодействия, оказывающий значимое влияние на настоящее и будущее сообществ, их институтов и граждан. Необходимы постоянные усилия, направленные на поддержание на технологическом и законодательном уровнях нравственных опор служения, участия граждан в жизни своего сообщества. Еще большее усилие нужно государству и обществу, чтобы отказаться от тюрем, признать свою ответственность за преступления, происходящие в них, чтобы найти и реализовать иные механизмы реабилитации и абилитации людей, совершивших нравственные и правовые проступки. Примеры - найкан и морита психотерапия, практики просветления Востока, практики пастырского окормления и духовного наставничества, социального служения и духовного покаяния в России, процессуальная и медиационная работа.

В целом, социально-психологическая абилитация и реабилитация осужденных и иных заключённых - процесс и результат формирования, восстановления и развития социально-психологических функций, ролей и статусов, отношений с собой и с миром у лиц, по тем или иным причинам в том или ином формате лишенных свободы. Эти функции, роли и отношения были не сформированы и / или утраченных данной группой людей в связи с обстоятельствами до, во время и после совершения преступления, осуждения и отбывания наказания в специфических условиях изоляции и более или менее законного ограничения в правах и обязанностях.

Эта многоуровневая и многоаспектная работа обычно начинается уже в СИЗО как разновидности исправительного учреждения и продолжается в постпенитенциарный период до тех пор, пока не будет установлена или восстановлена способность индивида к полноценному социально-психологическому функционированию и развитию. Ее 
эффективность и успешность достигается применением системы абилитационных и реабилитационных подходов и технологий: медицинских, психологических, педагогических, социальных, юридических, экономических и иных. В эту систему входит ряд моментов, среди которых важнейшее место занимают адаптация к жизни в тюрьме и ресоциализация заключенного. Первое направление включает в себя работу с психосоциальным состоянием человека, находящимся под следствием или осужденного к заключению (изоляции).

Обычно в следственных изоляторах условия содержания существенно труднее, чем в колониях общего и строго режимов, они близки по нагрузке на человека к тюрьмам и колониям усиленного и особого режимов. Однако, являясь практически невиновными, заключенные начинают нести наказание, часто превышающее меру ответственности за формально совершенное ими преступление_или, в современной России все чаще, будучи полностью непричастными к совершенному преступлению. Еще одна серьезная задача - профилактика конфликтов в сообществе заключенных и между заключенными и сотрудниками тюрем и СИЗО, в том числе посредством развития культуры общения и отношений у заключенных и сотрудников, мер профилактики и коррекции состояний профессионального выгорания у сотрудников.

Подходы и направления психологической помощи заключенным. Психологическое сопровождение в пенитенциарных учреждениях опирается на разные подходы: психоанализ и концепции личности преступника Ж. Пинателя и др.; трансактный анализ Э. Берна, ролевые игры и социодрама Дж. Морено и концепции социальной и личностной (не)зрелости человека; бихевиоризм и необихевиоризм и концепции модификации привычек / асоциального поведения Б. Ф. Скиннера, когнитивное и гуманистическое направления, в том числе гештальттерапия; рациональная терапия и воздействие с реальностью У. Глассера, общинная терапия М. Джонсона и пастырская помощь и т. п., позволяющие оценить «преступную способность» и / или ресоциализированность человека.

Ни один из принятых подходов не имеет преимущества. Эффективность и продуктивность помощи зависит, скорее, от самих заключённых и психологов, а также особенностей пенитенциарной системы страны. В США и некоторых других странах психологические методы также используются вместе с иными для наказания, в том числе пыток заключенных: узаконенных правилами «пенитенциарных» систем (стресс-терапия, изоляция и т. д.). Оправданием служит следующий 
типичный тезис: «преступность ...это социальная зараза, и общество вправе лечить ее при помощи наказания... Общество вправе принудить заключенного по примеру того, как оно принуждает лечиться или принудительно лечит заразного больного»20. В результате, например, тюрьмы становятся «реабилитационно-оздоровительными центрами», камеры одиночного заключения и карцеры - «центрами адаптации и уединения или медитации». Этот поход работает, но тогда, когда опирается на идею сохранения независимости и самоуважения заключенного: не только персонал учреждения, но и сами заключенные должны нести ответственность за свое исправление и ресоциализацию ${ }^{21}$. Иначе тюрьма становится «фабрикой преступлений», способствуя усилению преступных наклонностей осужденных, росту рецидивов, тюремнизации и стратификации людей под влиянием групповых норм и неформального кодекса «тюремного закона» (Д. Конрад, Р. Когрейн, К. Шрев, Г. Сайке, Д. Кресси, У. Бунденсон, Д. Стрит и др.). Поэтому личная и социальная трансформации и реинтеграции должны быть связаны в единый комплекс (М. Ансель, В. М. Поздняков) ${ }^{22}$. Интересная методика разработана Р. и М. Гулдинг: «психотерапия нового решения». Клиент высвобождает детский опыт и может избавиться от принятых в детстве ограничительных решений (запретов и указаний родителей). Он может принять ответственность на себя за все, что происходит в его жизни: обычно человек перекладывает свои проблемы на других, виня мир, но не себя. Принятие ответственности снимает многие барьеры и блокады отношений и развития, человек взрослеет. Другое успешное направление психотерапии с заключёнными психосинтез Р. Ассаджиоли, его цель - гармонизация и интеграция всех качеств и функций человека, его субличностей. Если некоторые их них

20 Шнайдер Г. Й. Криминология. М.: Издательская группа «Прогресс»«Универс», 1994.504 с. С. 412-414.

21 Бовин Б. Г., Голубев В. П. и др. Рабочая книга пенитенциирного психолога. М: МВД, 1998. 109 с.; Димитров А. В., Сафронов В. П. Основы пенитенциарной психологии. М.: Московский психолого-социальный институт, 2003. 176 с.; Новиков В. В., Мокрецов А. И.Личность осужденного: сочиальная и психологическая работа с различными категориями. Учебно-методическое пособие. М.: НИИ ФСИН России, 2006. 214 c.

22 Ансель М. Новая социальная защита (гуманистическое движение в уголовной политике). М.: Прогресс, 1970. 312 с.; Поздняков В. М. Психология в пенитенциарной практике зарубежных стран в ХХ столетии. Историко-сравнительный анализ. М.: Издво Акад. управления МВД России, 2000. 270с.; Митфорд Дж. Тюремный бизнес / Под общ. ред. и с вступ. ст. И. Б. Михайловской. М.: Прогресс, 1978. 349 с. 
занимают «центральное место», то ими нельзя управлять: они управляют человеком. Осознав свое истинное «Я», человек может управлять своими состояниями, становится гармоничным и счастливым. Еще одним из интересных направлений выступает нейролингвистическое программирование (НЛП), которое исходит из того, что человеческий организм подобен компьютеру, но большая часть «программ» не осознается, при этом возможно осознание и / или «перепрограммирование» (в том числе самопрограммирование человека). Задача специалиста - «встретить клиента там, где он находится» и активизировать ресурсы клиента, который знает способ решения своей проблемы, даже когда ему кажется, что не знает». В трансе (измененном состоянии сознания) применяется рефрейминг и разработка альтернативных или дополнительных программ; осуществляется «экологическая проверка» содержаний переживаний и преставлений, происходит диссоциация человека и страдания, помогающая найти новые пути разрешения проблем ${ }^{23}$.

Общие психологические компоненты исцеления, такие как доверие, надежда, переоформление и миропонимание были неоднократно идентифицированы как психотерапевтические факторы в самых разных культурах и подходах. Поэтому на Западе пенитенциарные психологи также интенсивно осваивают восточные практики, расширяющие традиционные когнитивно-бихевиоральные и гуманистические модели.

Особенно интересны, на наш взгляд, «morita-терапия» и «naikanтерапия». Найкан («nye-kahn») представляет собой структурированный метод интенсивной медитации на нашу жизнь, наши взаимосвязи, наши ошибки и провалы, достижения и успехи ${ }^{24}$. Целью терапии является повышение осведомленности о себе, а также признание без осуждения. Подобно морита-терапии и другим восточным подходам и практикам, основное внимание уделяется прежде всего трансперсональному и

\footnotetext{
${ }^{23}$ Антонян Ю. М., Эминов В. Е. Личность преступника. Криминолого-психологическое исследование. М.: Норма: Инфра-М, 2010. 368 с.; Данилин Е. М., Строева Г. В. и др. Характеристика личности осужденного (социально-психологический портрет). М: НИИ УИС Минюста России, 2004. 42 с.; Деев В. Г., Казакова Е. Н., Михалева И. В., Наприс А. В. Основы психологии исполнения уголовных наказаний. Вологда: ВИПЭ Минюста России, 2001. 347 с.

${ }^{24}$ Krech G. Naikan: Gratitude, Grace, and the Japanese Art of Self-Reflection Paperback. New York: Stone Bridge Press, 2001. 220 p.; Miki Y. Naikan Therapy. A Way of Self-Discovery and Self-Renewal. New York: Weissman Press, 2015. 54 p.; Schuh J. Naikan The World of Introspection. Bielefeld: Tao De in J. Kamphausen Mediengruppe GmbH, 2016. 258 p.
} 
экзистенциальному уровню нарушений внутри и вне человека, очень мало внимания связывается с «физическими» и «психическими» патологиями самими по себе. Терапия найкан позволяет человеку осознать, что он несет ответственность за то, как относится к другим людям и окружающей среде. Через найкан люди развивают естественное и глубокое чувство благодарности за благословения, даруемые им другими, благословения, которые всегда были, но остались незамеченными.

Морита-терапия - целецентрированный, ориентированный на «ответ» психотерапевтический метод С. М. Морита. Морита-терапия использует психологические эффекты сенсорной депривации. Методы терапии включают в себя эмпатическую редукцию (fumon) (цель - отвлечь внимание пациента от его диффузных, субъективных жалоб и уделить время и место конкретными фактами, потребностям и деятельности, не игнорируя симптомы, но лишь подтверждая их наличие, не изучая их), обучение опытом (taitoku). Цель - научить клиента принимать проявляемые им симптомы как часть своей жизни (жизнь ивы - с ее гибкими ветвями, «bending willow tree»). Пациент не должен ждать улучшения, но может и должен участвовать в жизни, несмотря на симптомы. Ему помогают инструкции терапевта, ориентация на дисциплину и совершенство. Успех и напряжение рождают импульс, побуждающие к развитию. Специалист должен поддерживать практические успехи и саморефлексию пациента 25.

Так, Е. С. Тарабрина описывает терапевтические сообщества, практикуемые в «открытых» исправительных учреждениях (примерно соответствующих российским колониям-поселениям). Созданная в середине XX века педагогом-пенитенциаристом М. Джоунзом, она направлена на создание нового типа исправительного учреждения, основанного на взаимоуважении и поддержке, в котором заключенные могли бы осмысленно присваивать способы и ценности законопослушного поведения. Организация жизни такого сообщества опирается на следующие принципы: 1. Продуктивная работа над собой нацелена на возможно более быстрое и безвозвратное возвращение на свободу. Любая деятельность персонала и заключённых нацелена то, чтобы заключенные возможно более полноценно и эффективно подготовились к освобождению и покинули исправительное учреждение равноправными членами общества, а не страшащимися его и себя изгоями. 2. Переориентация

\footnotetext{
${ }^{25}$ Li C., He Y. Morita therapy for schizophrenia // Schizophrenia bulletin. 2008. Band 34. S. 1021-1023.
} 
заключенных в процессе образовательных групповых и индивидуальных программ. 3. Заключенные включены в управление учреждением, занимая в нем ряд административных должностей. Они также не живут в запирающихся на засовы «камерах»: в течение дня люди заняты трудом и вечером отдыхают в своем жилище. Ежедневно они собираются малыми группами, чтобы обсудить работу учреждения, сформулировать предложения администрации по улучшению его работы, внести собственные предложения, проанализировать свои и окружающих поступки и отношения между заключенными и персоналом²6.

Другие программы, как отмечает С. Е. Тарабрина, носят социальный характер (Social Therapy Programs), например, программы-форумы: они дают возможность людям оказаться в ситуации, где они открыто могут обсуждать темы, влияющие на их жизнь, иметь собственное мнение, говорить правду без страха, что впоследствии придется «расплачиваться». Атмосфера на сессиях / встречах форума максимально приближена к ситуации общения на свободе, но более продуктивна и обращена к рефлексии, в то время как «на свободе» большая часть общения фактический «треп». Данная программа существенно облегчает пребывание в учреждении, заменяя «отбывание наказания» развитием. Хотя многие заключенные включаются в нее не сразу, опыт демократии, уважения, внимания, терпения, делает свое дело. В самом начале непривычность ситуации «форума» создает иллюзию обмана и вызывает неприятие и отчуждение, но после периодов анархии, демонстраций эгоизма и недоверия, люди научаются уважать специалистов и друг друга и совместно принимать многие важные решения, развиваются приятельские и дружеские отношения, трансформируется модель общения и речь, люди уходят из своей «незавидной роли» изгоев и принимают новую роль равноправных граждан, которые понимают и разделяют задачи, стоящие перед целым обществом и могут выдвинуть, поддержать и реализовать конструктивное решение. Здесь также есть и обучающий аспект: но преимущество такого обучения перед обычными занятиями «по предметам» состоит в том, что они связаны с разными областями науки и практики, а все участники (заключенные, преподаватели-наставники,

26 Тарабрина С. Е. Социальные программы для лиц, отбывающих наказание в исправительных учреждениях США // Гуманитарно-пенитенциарный вестник: науч.-публицист. альманах / Под общ. ред. Ю. А. Реента. Рязань: Академия права и управления Федеральной службы исполнения наказаний, 2008. Вып. 3. 173 с. С. 99 100; Duguid S. To Inform Their Discretion: Prison Education and Empowerment / / Journal of Correctional Education. 1988. Vol. 39 (4). Pp. 174-181. 
преподаватели-специалисты) равны. Эта программа дает возможность расширить нравственный кругозор, выработать рефлексию, самостоятельное и критическое понимание себя и мира, достичь отношений уважения и доверия, что имеет важное значение для будущей жизни (семьи и труда) за пределами тюрьмы. Происходит освобождение от чувства одиночества, неуверенности, беспомощности, наблюдается рост самоуважения и самоэффективности ${ }^{27}$.

Отдельно выделяются религиозные программы (Religious Programms). Они есть во всех исправительных учреждениях США и многих развитых странах, для всех заключенных, что связано с законами, гарантирующими свободу вероисповедания. Внедрение этих программ, как уже отмечалось выше связано с давно известным фактом о том, что у заключенных верующих и у заключенных, принимающих участие в религиозных программах, привыкание к условиям заключения проходит менее болезненно, чем у «неверующих» и не вовлеченных в работу. Религиозные программы и ритуалы выступают в качестве психологической помощи, в том числе защиты от негативных событий и лиц в окружающем их мире. Религия помогает сохранить связи с семьями и сообществом в целом, а также - с самими собой, что дает возможность более гармоничного возвращения после освобождения. Сотрудники религиозных организаций проводят в исправительных учреждениях групповые и индивидуальные беседы и занятия по изучению Библии, других текстов и нравственных основ религий в целом. Для этого издаются специальные учебники и журналы. Кроме того, существует переписка добровольцев с заключенными, обеспечение последних литературой по той или иной религии, по юриспруденции, касающейся прав заключенных, оказание духовной поддержки как во время отбывания наказания, так и после освобождения. Большинство заключенных, с которыми работает такая организация, не обязательно являются верующими и обычно лишь стремятся обрести покой и гармонию внутри себя. Религиозные организации также организуют специальные занятия, где заключенные обучаются выживанию в обстановке исправительного учреждения и

27 Тарабрина С. Е. Социальные программы для лиц, отбывающих наказание в исправительных учреждениях США // Гуманитарно-пенитенциарный вестник: науч.-публиист. альманах / под общ. ред. Ю. А. Реента. Рязань: Академия права и управления Федеральной службы исполнения наказаний. 2008. Вып. 3. 173 с. С. $98-$ 99; Gehring T., Muth W. R. The Correctional Education. Journal of Correctional Education. 1986. Vol. 37 (1). Pp. 14-17; Kunen J. S. Teaching Prisoners a Lesson // The New Yorker. 1995. № 7, July. Pp. 34-39. 
готовятся к тому, чтобы вести достойную жизнь после освобождения. В комплекс занятий входит обучение молитвам и медитациям, ведению дневников и журналов, теории и практике йоги, иным философскорелигиозным концепциям и практикам. Иногда такие программы используются в корыстных целях: программы дают возможность получения ряда привилегий, а также могут использоваться с целью завоевать хорошую репутацию, продемонстрировав мнимую религиозность, чтобы вызвать у персонала пенитенциарного учреждения и / или у комиссии, выносящей постановление об условно-досрочном освобождении, иллюзию «исправившегося» 28 . Однако, в целом, позитивное влияние таких программ существенно превосходит негативные, несмотря на утверждения критиков реабилитационного подхода, возмущенных идеей помощи преступникам, «зекам» и т. Д.

Выводы. Моделей много. Мало пока лишь действительного и действенного стремления, осознания обществом и государством как собственных потребностей, нужды - остановить и признать свои собственные преступления, исправить допущенные ошибки и компенсировать по возможности нанесенный людям вред, создав новую систему помощи людям, совершившим или могущим совершить нравственный и правовой проступок. Однако, государства и «гражданские общества» многих стран пока что не только не заинтересованы в помощи другим, но, напротив, выстраивают все больше оборонительных и репрессивных барьеров в отношениях друг с другом. Осуждённые выброшенные и изолированные от общества физически, социально и психологически - никому не интересны. Не удивительно, что они переполнены разочарованием, мстительной злобой и ненавистью к себе и миру.

Человечество зашло на пути насилия и рабства достаточно далеко, чтобы уничтожить само себя. Если в ближайшие годы не будет проведено несколько крупных тюремных реформ и, шире, правоохранительных реформ, на уровне ведущих и крупнейших государств (ЕС, США, Россия, Китай и Индия), то с надеждами о «стабильном развитии» не только они, но и весь мир вынуждены будут расстаться.

Dr. Prof. Mariam Arpentieva (Kaluga, Russian Federation)

RELIGIOUS, SOCIAL AND PSYCHOLOGICAL WORK IN THE CRIMINALEXECUTIVE SYSTEM IN THE LATEST TIME

${ }^{28}$ Education in U.S. Prisons: Survey Summary // Corrections Compendium. 1994. № 3, March. Pp. 5-6. 
The development of a complex of scientific research and methods, as well as applied directions and technologies of spiritual and moral education of convicts in correctional institutions in modern conditions is part of the system of social service that is becoming increasingly important for society and the state. This assistance is necessary not only for the convicts and employees of penitentiary institutions, but for the entire lawenforcement and human rights system of countries, for the entire state, for the people.

Keywords: Penitentiary Institution, Spiritual and Moral Upbringing, Psychological Help, Pastoral Help, Secular Help.

Мариям Арпентьева (Калуга, Российская Федерация)

\section{РЕЛИГИОЗНАЯ И ПСИХОЛОГИЧЕСКАЯ ПОМОЩЬ ЗАКЛЮЧЕННЫМ В НОВЕЙШЕЕ ВРЕМЯ: ПОДХОДЫ И МОДЕЛИ}

Развитие комплекса научных исследований и методов, а также прикладных направлений и технологий духовно-нравственного развития личности осужденных в исправительных учреждениях в современных условиях - часть приобретающей все большее значение для общества и государства системы социального служения. Автор доказывает, что эта помощь необходима не только осуждённым и сотрудникам пенитенциарных учреждений, но и всей правоохранительной и правозащитной системе стран, всему государству, народу.

Ключевые слова: пенитенциарные учреждение, духовно-нравственное воспитание, социально-психологическая помощь, пастырская помощь, светская помощь.

Маріям Арпентьєва (Калуга, Російська Федерація)

РЕЛІГІЙНА ТА ПСИХОЛОГІЧНА ДОПОМОГА УВ'ЯЗНЕНИМ В УМОВАХ СЬОГОДЕННЯ: ПІДХОДИ ТА МОДЕЛІ

Розвиток комплексу наукових досліджень і методів, а також прикладних напрямів i технологій духовно-морального розвитку особистостей, засуджених до відбування покарання у виправних установах - частина набуваючої все більшого значення для суспільства і держави системи соціального служіння. Автор доводить, що ця допомога необхідна не тільки засудженим і співробітникам пенітенціарних установ, але також усій правоохоронній і правозахисній системі країн, кожній державі, всьому народу.

Ключові слова: пенітенціарні установи, духовно-моральне виховання, соціальнопсихологічна допомога, пастирська допомога, світська допомога.

* Арпентьева Мариям Равильена - доктор психологических наук, профессор кафедры психологии развития и образования Калужского государственного университета им. К. Э. Циолковского. E-mail: mariam_rav@mail.ru. 